\title{
George R. Call: A Pioneer in Ham Radio
}

\author{
Miriam Baker Nye
}

MANY OF THE HOBBIES people choose prove to be passing fancies, but not so with the avocation of George R. Call of Sioux City, Iowa. He maintained an interest in amateur radio over a period of sixty years. ' Attracted to this field during his early adolescence, Mr. Call participated in several "firsts" in the history of ham radio. While his business career led him into investment banking and real estate, his enthusiasm for ham radio never waned. The three decades he continuously experimented with radio transmitting have been ones in which significant scientific advancements have occurred.

George Call became a "ham" after constructing his own set from make-shift parts; he subsequently received the first radio message transmitted in Sioux City. As a teen-ager he instructed men of a Signal Corps Battalion in World War I in radio transmission, and he helped achieve one of the earliest, if not the very first, broadcasts of an athletic event.

Call's birth on May 22, 1898 occurred at a time when the famous inventor Marconi was experimenting with wireless communication in London, between St. Thomas's Hospital and the British House of Commons. ${ }^{2}$ In 1906 , after a trip on a British ship equipped with a wireless, Call's parents offered to buy him a

'George R. Call was known to the author for forty-five years. During 1972 and 1973 special interviews were conducted in preparation for this article. $\mathrm{Mr}$. Call died in July. 1974.

${ }^{2}$ The Yearbook of Wireless Telegraphy and Telephony (New York: The Marconi Publishing Corporation, 1914) p. 22. 
radio set of his own. The commercially-made set was already assembled and mounted on a board similar to a bread-board. Thirteen-year-old George thanked his father, but preferred to build his own set, following instructions he saw printed in the pages of the Sioux City Daily News.

An article entitled "How to Build a Wireless Set" spurred him to study scientific magazines, acquire materials, and improvise some of the parts with which he constructed his first receiving set. He made a "cat-whisker" detector out of a darning needle and galena crystal he had purchased. For the inductive tuner he borrowed his mother's rolling pin, wound it with wires, and filed the insulation off to permit sliding contact. When George needed filings for the coherer, he at first filed a five-cent piece, unaware of any legal prohibition against defacing coins. Later he discovered he needed iron filings.

He had to buy a variable condenser, but to make his transmitting condenser, he used tin foil from tobacco packages. He stuck the foil on eighteen-inch double-strength glass with shellac, leaving a one-inch border. He also built a spark gap from two rods pointed at each other. Power came from a Ford automobile spark coil hooked to a battery. It made a spark because it was high voltage. The spark gap was two rods with brass balls properly placed. The more power, the greater spacing required between the balls.

Ed Preston, another Sioux City boy, who lived in a house on Seventh Street north of where the main public library now stands, had also been inspired to work with radio. He constructed a sending set. The first radio message ever transmitted and received in Sioux City is believed to be the one Ed Preston broadcast late in the winter of 1912. George Call picked it up on his home-made receiver in the basement of his parents' home at 1529 Grandview.

"I can't remember just what the message was," Call said, "but I do remember the great kick we kids got out of sending and receiving it." As other boys became interested, a radio club was organized, including Howard White, Joe Dean, Preston and Call.

The boys used the initials of their own names as a means of identification. Messages were sent in the international code of dots and dashes. To find out whether a message had been received, it was necessary to telephone or to make a quick trip to the receiver's home. 
Shortly after the United States' entrance into World War I, federal agents shut down all amateur stations, and George Call lost his station at the home on Grandview Boulevard. But in 1917 he acquired his first license, with the call letters 9IQ. It was not uncommon then to talk regularly with Omaha, the Twin Cities, and other midwestern points. Canada and Mexico were reached occasionally.

During World War I, when George Call, Joe Dean, and Howard White were in their late teens, they were asked to teach radio theory and code to a full battalion of the Signal Corps in Sioux City. Most of the pupils were older than their teachers. The classes were conducted under the supervision of the board of education and Superintendent M. G. Clark.

In the early fall of 1918, while stationed at New Haven, Connecticut with the 3rd Service Company, Eastern Department, U.S. Signal Corps, George Call took part in broadcasting and receiving one of the earliest (perhaps the very first) play-by-play of an athletic event-a football game in Yale Bowl, though not a university game. The receiving equipment was placed around the field at six different locations. Part of the equipment was placed at East Rock Park, and part of it on the Yale quadrangle.

George Call sold one of his early radio sets to young Ernest Lawrence in 1919 for use at the University of South Dakota in Vermillion. Call had assembled the single-kilowatt spark transmitter, generating about 1,000 watts, in 1916 and 1917. Ernest Lawrence and his brother John took the transmitter and Call's receiving set to the university, where they developed active radio communications. Ernest Lawrence, who died in 1958, became widely known as the inventor of the cyclotron, won the 1939 Nobel prize for physics, and collaborated with Enrico Fermi in developing the atomic bomb.

In 1920, radio equipment was installed on a special railroad parlor car which was part of a Sioux City Chamber of Commerce booster trip to Chamberlain, South Dakota. George Call and Joe Dean literally crawled all over the Chicago, Milwaukee, St. Paul and Pacific car that accommodated the C. of C. members, in order to fit it with a loop antenna. Copper wire was strung around four points on top of the car. Insulators held the wire off the car's metal top. The aerial had to be constructed low enough to pass 
under bridges and trestles. George's home-made receiving set was used, plus some commercial equipment. Home-town news from Station WEAU, located in the Davidson Brothers Building in downtown Sioux City, was received with amazing clarity by about 100 travelers who had gone to Chamberlain. WEAU was heard in the railroad car across a distance of 200 miles!

In 1921 George Call, Howard White, Joe Dean, and B. W. Nestlerode set up Sioux City's first broadcasting station, an experimental station located between two water reservoirs in Grandview Park. It was a 5,000-watt station with the call letters 9ZU. The first voice the four radio enthusiasts heard in answer to a call was from the university station at Vermillion, South Dakota. There were no set programs. All messages consisted of social conversations. Messages flew back and forth at all times of the day and night. If one of the four young men did not wish to converse, there were "always kids hanging around clamoring to use the radio." ${ }^{3}$

Amateur station 9ZU had a transmitter of the type popularly known as a "rock crusher," the kind which preceded the CW type. It had a rotary spark, 5 kilowatts input, 375 meters, with 9 amps in the antenna, and a communication range bounded by the North American continent. There were four wire flat-top antennae with sixty-foot support towers. General amateur stations of the era were limited to one kilowatt at 200 meters. $^{4}$

During his sixty years of amateur radio hobbying, George Call made thousands of contacts throughout the world. He contacted Perth, on the western tip of Australia, 11,500 miles away and the most remote land station which can be reached from Sioux City. Like other "hams," he found that his hobby was the means to greater world friendship and understanding.

To become a licensed operator in this country, one must be a

${ }^{3}$ The Sioux City Journal, April 2, 1939.

"Station 9ZU's "shack" was built by Sioux City as a dressing and lunch room for maintenance crew, with accomodations for the radio station, a potential emergency communication center. It is interesting to note that the term "shack" for radio station had its origin in Marconi's day. To facilitate ship-to-ship and shipto-shore communication, the radio operator and his equipment were housed in a superstructure above the ship-in a little wooden shack close to the antenna. As amateurs became involved in radio, they called the room or the place or the station where they sent and received, the "shack," no matter how durably or even luxuriously it was constructed. 
United States citizen, must be able to answer certain technical questions relative to radio theory, must be proficient in sending and receiving code at the prescribed speed, and conversant with radio regulations and laws. Some operators are shut-ins and/or physically handicapped. The Federal Communications Commission allows no fees to be collected by "hams" for relaying messages or for rendering emergency service.

George Call experienced some of his deepest satisfactions in aiding relatives and friends of service men stationed abroad who were able to talk with absent soldiers, sailors, marines, or airmen by means of a hook-up between Call's station and another overseas. In one instance, a small boy and his mother came to the Call home at $20 \mathrm{McD}$ onald Drive after George had learned that the husband and father, an army major, was desperately lonely for his family at his post on the island of Guam. The young wife was somewhat shy about accepting the invitation to communicate, issued by a man who was a complete stranger. But George and Alice Call soon put her at ease. When her little son recognized his father's voice he announced jubilantly, "That's my Daddy!"

In the winter of 1948 George Call used his 300-watt "Ham" station to contact an Argentine short-wave station, and afterward sent a card confirming the conversation with the operator who talked with him. To his great surprise, he received a flowery reply from Juan R. Duarte, secretary to Juan D. Peron, then dictator of Argentina. George had unknowingly talked with Presidente Peron himself, also an avid "ham."

The letter, postmarked March 29, 1948 from Buenos Aires, read:

Juan R. Duarte greets very affectionately Mr. Jorge R. Call and takes pleasure in acknowledging receipt of the card directed to the most excellent Mr. Presidente, which has been directed to the secretary for comment in appreciation of the kindness of your consideration.

The evolution of "call" letters for George began with the use of his own initials when he and his youthful friends first sent and received messages with their home-made equipment. In 1917, George's licensed station had the call letters 9IQ. Later the practice of assigning certain alphabetical and numerical prefixes, according to the country and district where a station was located, resulted in his having the letter $\mathrm{W}$ (one of the prefixes for the 
United States) and the number 10 for the tenth district.

In an interview with Sioux City radio station KSCJ's Bill Dingwell in 1964, Call was asked to evaluate some of the early development which led to present-day electronics. He paid tribute to many inventors and experimenters, but noted especially the work of a native Iowan, Dr. Lee De Forest for a 1906 invention of the three-element radio tube.

Concerning his own accomplishments and his participation in several significant "firsts" of amateur radio operation, his Old Timer's Certificate, and his Certificate of Merit from the Armed Forces Communications Association, George Call was very modest. But his "ham" associates, as well as the many people whom he helped by pursuing his long-time hobby, agree that his was a worthy contribution.

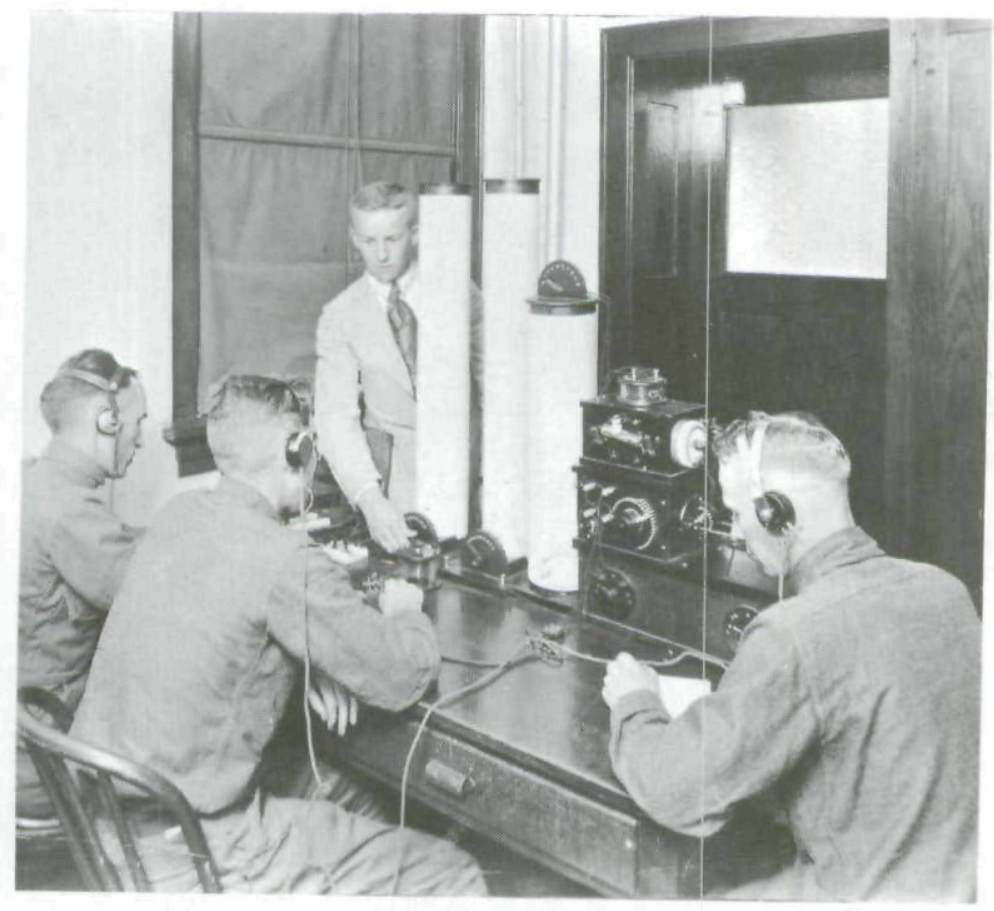

Photograph courtesy of Mrs. George Call.

In the summer of 1918 George Call [standing] instructed members of the U.S. Signal Corps Battalion in radio theory. 
Copyright of Annals of Iowa is the property of State of Iowa, by \& through the State Historical Society of Iowa and its content may not be copied or emailed to multiple sites or posted to a listserv without the copyright holder's express written permission. However, users may print, download, or email articles for individual use. 